\title{
ЭКОЛОГИЧЕСКИЕ АРХЕТИПЫ СКВОЗЬ ПРИЗМУ СНОТОЛКОВАНИЙ, СОДЕРЖАЩИХ ОБРАЗЫ ПТИЦ
}

B статье рассматриваются орнитообразы, представленные в толкованиях разноязычных сонников. Анализ данных снотолкований выявляет в них отражение таких экологических архетипов как архетип вселенского закона, архетип единства и ичкличности бытия, архетипь мужественности и женственности.

Ключевые слова: экологический архетип, архетип вселенского закона, архетип единства и ичкличности бытия, архетипь мужественности и женственности, снотолкование

The article discusses bird images, represented in books of dream interpretations written in different languages. The analysis of the given dream interpretations reveals the reflection of such ecological archetypes as the archetype of the Universal law, archetype of the unity and cyclic nature of being, archetypes of manhood and womanhood.

Key Words: ecological archetype, archetype of the Universal law, archetype of the unity and cyclic nature of being, archetypes of manhood and womanhood, dream interpretation

Информация, заложенная в снотолковании, характеризуется многослойностью и может быть представлена, во-первых, в виде общекультурных, общечеловеческих смыслов, во-вторых, в виде этноспецифических культурных смыслов и, в-третьих, в виде личностных, индивидуальных смыслов. Общечеловеческие смыслы сопоставимы с архетипами коллективного бессознательного, оттого имеют тесную связь с мифическим мировосприятием. Сближая бессознательную логику мифа со сновидениями, К. Юнг определяет курьерскую роль их символики: они транслируют «послания от инстинктивных к рациональным частям разума» [Юнг 1998: 46]. 
Этноспецифические культурные смыслы основаны на обрядах, традициях, верованиях, житейском опыте, потому отличаются разнообразием и могут быть адекватно интерпретированы с учетом реалий того или иного этноса. Личностные смыслы зависят как от жизненного опыта индивида, так и от его психоэмоционального состояния. Именно на этом уровне, в конечном итоге, преломляются сквозь личностный опыт, как сквозь «семиотическое зеркало» (в трактовке Ю.М. Лотмана), архетипические и этнокультурные смыслы, вызывая к жизни всевозможные ассоциации и интерпретации. Таким образом, в традиции К.Г. Юнга сновидения воспринимаются как осмысленные сообщения личного характера, в которых используются общие для всего человечества символы. При этом один и тот же символ, приснившийся разным людям, не будет интерпретироваться одинаково.

Сонники, как правило, представляют толкования отдельных сновидческих образов, а само снотолкование, будучи культурным текстом, призвано вербализовать тот или иной архетипический или этнокультурный смысл в языковых единицах.

Цель настоящего исследования заключается в том, чтобы выявить экологические архетипы в снотолкованиях, содержащих орнитообразы. К исследованию привлечены материалы русско-, англо- и французскоязычных сонников [Артемидор 1989-1991, Собрание сонников, Подрецкая 1996, Смурова 2011, Цветков 1997, Craig 1918, Dream Dictionary, Kurth 1977]. За отправную точку взяты архетипы единства человека и природы, определенные В.В. Флоренской в ходе реконструкции и семантического анализа посвятительных обрядов, мифологических и фольклорных сюжетов, свойственных разным национальным культурам [Флоренская 2010]. Аналогичные экологические архетипы, а именно: архетип вселенского закона, архетип принадлежности к роду, архетип дома, архетипы мужественности и женственности выявлены при исследовании паремий русского, английского и французского языков [Курашкина 2020].

Пространственно-временные ориентиры в мифическом мировосприятии задает образ летящей птицы, которая выполняет функцию связующего звена между миром сакральным и миром профанным. По этой причине с незапамятных времен птицы 
воспринимаются как божества, с одной стороны, и как вестники, с другой. Любой онейрический образ птицы, таким образом, представляет собой реализацию архетипа вселенского закона. К ядру снотолковательной прогностики тяготеют такие орнитообразы, как аист, воробей, ворон/ворона, голубь, гусь, жаворонок, кукушка, курища, ласточка, лебедь, орел, павлин, петух, попугай, сова, соловей, сорока, утка, филин, чайка, ястреб. Периферийные орнитообразы - это альбатрос, бекас, вьюрок, глухарь, грач, гриф, дрозд, дятел, зяблик, иволга, индюк, канарейка, коршун, куропатка, пеликан, перепел, рябчик, селезень, синица, скворец, сокол, стервятник, страус, тетерев, фазан, ичапля, чиж.

Мысль о конечности существования всего живого всегда присутствует в сознании и хранится в коллективном бессознательном. Именно птицам суждено возвещать человека посредством сновидений о ключевых моментах его жизненного цикла: рождении, создании семьи, уходе из жизни. Так реализуется архетип единства и цикличности бытия. Сновидческий образ аиста связан с появлением потомства и считается счастливым предзнаменованием. Онейрические образы канарейки, ласточки и соловья ассоциируются с бракосочетанием и предвещают счастливую супружескую жизнь. Определенные образы птиц в сновидениях неизменно связываются со смертью (ворон / ворона и сова), да и сама смерть как фольклорный образ - это «пернатый человек-птица со страшными когтями и лицом упыря» [Назиров 2010: 176].

Сновидческие образы несут в себе отголоски племенного тотемизма, основанные на оппозиции «свой - чужой» (архетип принадлежности к роду), а распределение всех объектов на служащих богу добра или богу зла приводит к тому, что одни птицы получают статус священных, а другие - демонических. Соответственно, в снотолкованиях появляются образы птиц, несущих добрые вести, противопоставленные вестникам худых новостей. Онейрические орнитообразы - преимущественно добрые вестники: аист, альбатрос, бекас, вьюрок, голубь/ горлица, жаворонок, зяблик, канарейка, ласточка, лебедь (бельий), синица, соловей, фазан. Так, увиденная во сне синица означает прибыль или честную победу. 
Преимущественно недобрые вестники: ворон / ворона, галка, гриф, коршун, кукушка, куропатка, попугай, рябчик, сова, сорока, стервятник, страус, тетерев, филин. Например, приснившаяся кукушка предвещает несчастье в личной жизни. В то же время амбивалентность самих орнитообразов зачастую проявляется в двойственной трактовке сновидений с их участием. Амбивалентными вестниками выступают: воробей, гусь, дрозд, журавль, индюк, курица, орел, павлин, перепел, петух, сквореи, сокол, утка, цапля, чайка, ястреб. К примеру, журавль в зависимости от сновидческих обстоятельств может свидетельствовать как о приятных новостях издалека, так и о неудаче в делах.

Реализация архетипов мужественности и женственности зиждется на известной оппозиции и уходит корнями в древние инициации. Если к мужским сновидческим орнитосимволам можно отнести образы петуха и ястреба, то курища и ласточка представляют собой воплощение женских орнитообразов. Так, онейрический образ ястреба трактуется как герой, воин, надежный друг, в то время как за образом ласточки кроется преданная и любимая женщина.

Подводя итог, необходимо подчеркнуть, что онейрические орнитообразы являются, в первую очередь, трансляторами архетипов вселенского закона и единства и цикличности бытия, связуя мир горний и мир дольний и очерчивая бытийные границы на пространственно-временной оси. Не меньшее значение имеют сновидческие орнитообразы, связанные с архетипами мужественности и женственности.

Традиция почитания и обожествления птиц, восходящая к древней мифической первооснове, не исчезает из культурной памяти. Древние символы наполняют сновидения, взывая к экосознанию каждого индивида о его неразрывной связи с нашим общим вселенским домом, который важно оберегать, поддерживая жизнеобеспечивающие отношения со всеми его обитателями.

\section{ЛИТЕРАТУРА}

1. Артемидор Далдианский. Сонник (Artemidori Daldiani Oneirocritica) / Пер. М.Л. Гаспарова, В.С. Зилитинкевич, И.А. Левинской, Э.Г. Юнца. Под общ. ред. Я.М. Боровского // 
Вестник древней истории. - № 4, 1989; № 1-4, 1990; № 1-3, 1991. [Электронный pecypc]. URL: http://annales. info/ant_lit/artemidor/ index.htm (дата обращения: 15.01.2021).

2. Курашкина Н.А. Реализация экологических архетипов в паремиях, содержащих образы птиц // Вестник Нижегородского университета им. Н.И. Лобачевского. - 2020. - № 2. - С. 280 289.

3. Назиров Р.Г. Архаические образы смерти и фольклор [2001] // Назиров Р.Г. О мифологии и литературе, или Преодоление смерти. Статьи и исследования разных лет. - Уфа: Уфимский полиграфкомбинат, 2010. - С. 174-181.

4. Подрецкая Л.С. Сонник. - Минск: Беларусь, 1996. - 262 с.

5. Смурова О.Б. Новый семейный сонник. - М.: РИПОЛ классик, 2011. $-704 \mathrm{c}$.

6. Собрание сонников. [Электронный ресурc]. URL:http:// www.sonnik-online.net/ (дата обращения: 12.03.2021).

7. Флоренская В.В. Архетипы единства человека и природы традиционных обществ и формирование экологической культуры: Автореф. дисс. ... канд. культурологии. Екатеринбург, 2010. - $22 \mathrm{c}$.

8. Цветков Е.П. Счастливые сны. Толкование и заказ. - М.: Континент-Пресс, 1997. - 352 с. - («Связь времен»).

9. Юнг К.Г. К вопросу о подсознании // Юнг К.Г. и др. Человек и его символы / Под общ. ред. С.Н. Сиренко. - М.: Серебряные нити, 1998. - С. 13-102.

10. Craig K.T. The Fabric of Dreams: Dream Lore and Dream Interpretation, Ancient and Modern. - New York: E.P. Dutton \&Company, 1918. $-380 \mathrm{p}$.

11. Dream Dictionary. [Электронный pecypc]. URL: www.dreammoods.com/dreamthemes/birds-dream-symbols.htm (дата обращения: 12.03.2021).

12. Kurth H. Dictionnaire des Rêves de A à Z / Traduit de l'allemand par R.J. Guiton. - Paris: Édition du Club France Loisirs, 1977. - 344 p.

(C) Курашкина Н.А., 2021 г. 